\title{
RELATO DE EXPERIÊNCIA NA RESIDÊNCIA PEDAGÓGICA EM FÍSICA EM UMA ESCOLA REGULAR DO TOCANTINS
}

Case Study in the Physics Pedagogical Residence in a regular school in Tocantins

Estudio de caso en el Residencia Pedagógica en Física en una escuela regular en Tocantins

\section{Anna Karollyni Lopes Sousa ${ }^{1}$, Maria Flavienne Araujo Reis ${ }^{1}$, Érica Cupertino Gomes ${ }^{1}$,} Edgar Duarte da Silva ${ }^{2}$

${ }^{1}$ Laboratório de Ensino de Física, Licenciatura em Física, Universidade Federal do Tocantins, Campus Cimba, Brasil.

${ }^{2}$ Colégio Pré-Universitário de Araguaína, Araguaína, Brasil.

*Correspondência: e-mail: carollynelopes0@gmail.com

\section{Artigo recebido em 05/03/2020 aprovado em 09/04/2020 publicado em 20/04/2020}

\section{INTRODUÇÃO}

A Residência Pedagógica é um programa que visa, dentre outros objetivos, o aperfeiçoamento da formação pedagógica dos discentes de cursos de licenciatura (Capes, 2018). O programa baseia-se na imersão no campo da prática e na articulação entre teoria e prática docente. Especificamente na licenciatura em Física tal programa é importante pois insere o residente na realidade profissional com a qual se deparará quando estiver formado, concedendo a ele uma visão ampla de como relacionar a prática com a teoria. Segundo Pannuti (2015),

A inserção dos acadêmicos no cotidiano da escola possibilita vivências em situações nas quais os professores utilizam os conhecimentos sobre o conteúdo a ser ensinado, os princípios gerais de ensino e de aprendizagem, além da didática, representando uma oportunidade para aprender a ensinar, integrando as dimensões teóricas e prática. (PANNUTI, 2015, p. 8436)

A Residência Pedagógica - RP transcende à prática do Estágio Supervisionado em função de suas estratégias de articulação entre a teoria e a prática, por exemplo, proporcionando maior tempo de ambientação e planejamento. Além disso, a regência realizada é mais ampla do que no estágio supervisionado, dado que envolve planejamento e execução de intervenções estruturadas, gestão da sala de aula, projetos dentre outras atividades.

O projeto da RP também valoriza a autonomia do residente, promovendo aplicações da teoria em situações reais, e na construção de ideias para solucionar desafios ou dificuldades, sempre sob a supervisão do professor da educação básica, que atua como preceptor e mentor. O residente também se apropria de diferentes metodologias estudadas ao longo do curso. $\mathrm{O}$ aperfeiçoamento docente do residente ainda é estimulado a partir da reflexão crítica. Sob esta perspectiva, este trabalho consiste em uma abordagem crítica reflexiva de residentes participantes do projeto Residência Pedagógica, do subprojeto de Física, da Universidade Federal do Tocantins (UFT), no Colégio Pré Universitário de Araguaína, Tocantins.

\section{METODOLOGIA}

Revista Desafios - v. 7, n. Supl. RP-UFT, 2020 
Trata-se de um relato de experiência de abordagem crítico-reflexiva sobre partes da vivência de residentes no programa RP. A residência foi realizada no Ensino Médio regular, em turmas de $1^{\mathrm{a}}$ a $3^{\mathrm{a}}$ séries, entre agosto de 2018 e janeiro de 2020 . As etapas escolhidas para a análise crítico-reflexiva foram:

II ETAPA: Ambientação dos residentes na escola e na sala de aula, envolvendo verificação da estrutura física da escola campo, a observação do Projeto Político Pedagógico da escola e reuniões de planejamento.

III ETAPA: Imersão do Residente na escola-campo, que englobou:

- Construção de planejamentos

- Pequenas intervenções

- Regência.

\section{RESULTADOS E DISCUSSÃO}

$\mathrm{Na}$ II etapa do projeto foi realizado o reconhecimento da estrutura física e do funcionamento da escola. Pudemos conhecer todos os funcionários e foi perceptível que todos contribuem e são responsáveis pelo o ensino de qualidade e para uma boa convivência harmônica dentro da unidade escolar. Aprendemos um pouco de como funciona cada setor e como se articulam. Posteriormente, iniciamos a análise do Projeto Político Pedagógico (PPP), no qual pudemos nos inteirar dos planos e objetivos da escola. Participamos de reuniões, aplicações de projetos e planejamentos como exibido na figura 1 , em um desses planejamentos aprendemos a elaborar planos de aulas contemplando as habilidades e competências que a Base Nacional Comum Curricular (BNCC) estabelece. Dentro desta etapa também recebemos dicas importantes para aproveitar com eficácia o tempo de aula.

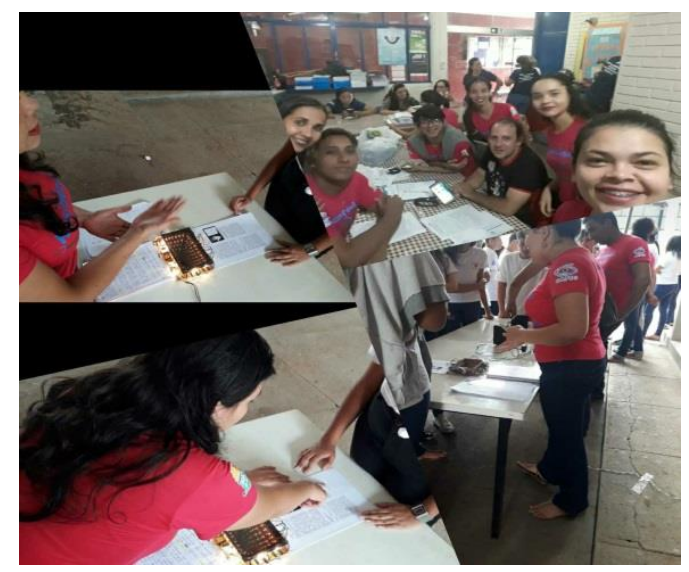

Figura 1. Residentes e preceptor no Colégio Pré-

Universitário - CPU

$\mathrm{Na}$ III etapa iniciamos a elaboração dos planejamentos e planos de aulas para começarmos a desenvolver pequenas intervenções como, por exemplo, ajudar a tirar dúvidas dos alunos, resolver pequenos exercícios, aplicar provas. Essa execução de atividades de maneira progressiva contribuiu para que nós residentes perdêssemos o nervosismo de lidar com uma sala de aula. O próximo passo dessa etapa foi as regências de fato, a ministração de aulas. Iniciamos a regência com os alunos das $3^{\text {a }}$ séries, depois fomos para as salas das $2^{\mathrm{a}}$ séries e finalizamos com os alunos das $1^{\mathrm{a}}$ séries.

A etapa da regência foi um momento ímpar no projeto para o crescimento, tanto acadêmico como profissional de todos os residentes. Destacamos o imenso aprendizado que tivemos nas elaborações dos planos de aula e sequenciamentos didáticos para uma melhor aprendizagem dos alunos, fazendo com que todo esforço e desafio valessem a pena. A regência é uma parte muito importante, pois é o momento em que temos o contato direto com os alunos e uma consciência do que de fato é ser um professor. Além de tudo, pudemos dividir os nossos conhecimentos com os alunos e aprender com eles.

Revista Desafios - v. 7, n. Supl. RP-UFT, 2020 
Ter passado por algumas turmas foi de total importância, pudemos ver e provar que a profissão docente é uma profissão que busca a melhoria para o futuro, pois não formamos apenas alunos ou profissionais capazes de exercer o que lhe for imposto, mas principalmente, formar cidadãos em busca de novos conhecimentos.

O ponto negativo, que destacamos em nossa experiência como residentes é a infraestrutura da escola. Embora os profissionais tenham sido receptivos e tenham contribuído muito para a nossa formação docente, o espaço escolar é pequeno para atender totalmente a necessidade dos docentes e discentes, as salas não são tão grandes e a biblioteca não comporta muitos alunos. A escola é destaque nas avaliações do IDEB, o que traz uma grande demanda de alunos e procura da comunidade.

\section{CONCLUSÃO}

A experiência com a residência pedagógica foi bastante significativa, aprendemos como fazer planejamento de aulas, conhecemos como funciona cada setor da escola e sua importância e vivenciamos um pouco da rotina de um professor de Física.

O diferencial da Residência Pedagógica (RP), em função do estágio supervisionado é que com a RP temos mais contato com a unidade escolar, ou seja, passamos maior ou grande parte do tempo na escola, convivendo com todo o ambiente e o que há acerca do mesmo, pois é neste ambiente que iremos atuar e trabalhar. A RP ajudou desenvolver metodologias para um ensino de qualidade, elaborar projetos com a participação dos alunos em feiras de ciências, sarau literário, festival de música e gincanas em geral.

A Residência Pedagógica contribuiu com grandes experiências para o futuro por meio das observações, reuniões na escola e na universidade, bem como na regência articulando a teoria e a prática. Os conhecimentos e experiências adquiridos são importantes para nós, quando formos de fato trabalhar como professoras na rede pública de ensino. As boas experiências, levaremos por toda a caminhada como educadoras, em busca de novos conhecimentos e compartilhando o aprendido.

\section{AGRADECIMENTO}

À CAPES, à UFT, ao CPU, à Prof. Dra. Érica Cupertino Gomes, ao Prof. Dr. Matheus P. Lobo, ao Prof. Ms. Edgar Duarte da Silva e a todos os residentes da Residência Pedagógica - Física/UFT.

\section{REFERÊNCIAS}

Edital CAPES 06/2018 que dispõe sobre a Residência Pedagógica. Disponível em https://www.capes.gov.br/images/stories/download/e ditais/01032018-Edital-6-2018- esidenciapedagogica.pdf. Disponível em 20 de maio de 2018.

PANNUTI, Maísa Pereira. A RELAÇÃ̃ TEORIA E PRÁTICA NA RESIDÊNCIA PEDAGÓGICA. XII congresso nacional de educação, ISSN 21761396, 2015 